\title{
Mediating Effect of Customer Skill on Educating and Co- Creation on Higher Education (Conceptual Paper)
}

\author{
Ahmad Efendi ${ }^{1}$, Muhammad Asdar ${ }^{2}$, Dian AS Parawansa ${ }^{3}$, Andi Reni ${ }^{4}$ \\ \{dedimks@gmail.com¹, masdar.ickn@gmail.com², dianparawansa62@gmail.com ${ }^{3}$, \\ andirenireni@gmail.com ${ }^{4}$ \}
}

Alauddin State Islamic University, Department Management ${ }^{1}$, Hasanuddin University, Department Management ${ }^{2}$, Hasanuddin University, Department Management ${ }^{3}$, Hasanuddin University, Department Management ${ }^{4}$

\begin{abstract}
The intense competition in the service industry has changed the company's perspective to pay more attention to consumers ' wishes. This new perspective is known as Service Dominant Logic. Along with this transition, the company develops the concept of co-creation with its customers so that the resulting products can meet customer desires. The purpose of this research is to build a conceptual framework of the effects of mediation of customer expertise in relation between customer education and co-creation on Higher Education (HE). Earlier studies suggested that there are several variables of the consumer resources that have a direct effect on co-creation. Among them are customer education, skills, experience, ideas, etc. But mostly researched in the context of manufacturing industry. There is still a little research of co-creation in the field of education services industry.
\end{abstract}

Keywords: Co-Creation, Customer education, Customer skill

\section{Introduction}

The evolution of marketing is now leading to a new dominant logic, which focuses more on intangible, dynamic, operant resources that are a source of competitive advantage and performance [1]. Service Dominant Logic was introduced by Vargo and Lusch in 2004 with a new approach, namely value co-creation resulting from a joint production process involving companies and customers [2].

Co-Creation Value is a process that provides opportunities for continuous interaction. Organizations share their world with outside stakeholders in order to generate benefits in the form of new insights. In this day and age, almost all companies want their customers to interact on their products and participate in new product development. This can develop consumer loyalty and confidence. Co-creation is widely accepted as a model for the concept of innovation and satisfaction [3].

New approach (SD Logic), companies apply the knowledge and capacity to produce and provide branding for products or services. Meanwhile, customers apply their knowledge and capacity in using the product [4]. Alves and Fernandes (2006), mention some customer operant resource variables that affect Co-creation activities [5]. Among them are customer education, self-efficacy, customer expertise, and social bridges. Alves found that all of these variables have a positive effect on co-creation activities. Alves also examines how customer education through customer expertise has a positive effect on co-creation activities.

Customer education is an activity carried out by companies by integrating the resources owned by the customer. By educating customers, companies equip customers with the capacities and capabilities needed to co-produce services [5]. 
Companies can complement customer capacities and skills through training and education and thereby increase their scope for co-creation. The greater the level of customer understanding of the opportunities available, the greater the vulnerability to co-creation [6].

By managing co-creation activities can help companies benefit from business relationships with customers. Companies are becoming more customer-oriented which fosters customer satisfaction and trust. In the end, co-creation activities will be beneficial for companies that maintain communication between the company and customers which will reduce risks and costs, as a competitive advantage strategy [3].

Uncles, M.D (2008) stated that the main activity of educational institutions is to provide educational services [7]. In several ways, higher education service activities can be compared to business activities in general, particularly service business activities. College in some ways can be equated and equated with a business company.

For HE to survive, it must carry out organizational management that adheres to the principles of good governance. Higher education also has its customers. The service industry must be customeroriented. HE should takes a high response to the desires of various students who become consumers [7]. Theoretically, the success of a company is determined by the company's ability to define who its customers are, and the ability to satisfy their needs [8].

Lewis and Smith stated that there are two higher education consumers, namely internal consumers and external consumers. Internal consumers consist of students, academic and non-academic staff, and departments / divisions in higher education, while external consumers are users of university graduates and services, donor agencies, alumni, and the National Accreditation Board [8].

Lewis and Smith specifically mentioned that as internal consumers, student needs consist of knowledge, skills, ability to achieve personal and professional goals, convenience in learning, and professional academic and non-academic staff services [8]. However, the requirements of students' needs as internal consumers are largely determined by the needs of graduate users as external consumers. Graduate users certainly need graduates who have high competence and are able to work together and work independently productively. For alumni, the need is pride because they have studied and obtained certificates / diplomas from certain tertiary institutions, for the National Accreditation Board their needs are related to control over the fulfillment of the criteria and standards set, while for donor agencies providing funding / scholarships the need is the fulfillment of the eligibility criteria for a management. college to get a cash injection. The feedback provided by higher education management is to determine the design / specification of educational services offered to students as internal consumers.

The activities of creating and using educational services in tertiary institutions occur together, so that students have the position of both workers and service users. Referring to Glasser's view, students can be positioned as consumers, but with low to moderate levels [8].

Constantin and Lusch (1994) in [4] say more operant resources produce an effect. The role of relative operant resources began to shift in the late twentieth century as humans began to realize that skills and knowledge were the most important types of resources. Service-dominant logic (S-D) introduced by Vargo and Lusch in 2004 brought a new approach to value creation resulting from a coproduction process involving both the company and the customer. [9]. In this new approach, suppliers apply their knowledge and capacity for the production and branding of products or services and customers apply their own knowledge and capacities to daily use [4].

Based on the explanation above, this paper will develop a conceptual framework for the role of mediating customer expertise on the relationship between customer education and value co-creation activities. 


\section{Method}

To discuss the topics studied in this paper, the literature review method is used. This literature review is intended to solve a problem which basically rests on a critical and in-depth study of the relevant library materials. Literature review is carried out by collecting data or information from various library sources that are needed as a source of ideas to explore new thoughts or ideas, as a basic material for deducing existing knowledge, so that a new theoretical framework can be developed, or as a basis for problem solving. The literature review approach consists of 3 stages consisting of: 1) searching the literature, 2) evaluating the literature, and 3) analyzing and interpreting the literature.

Literature sources studied in this paper are: research results, journals, and other scientific articles. The steps for making a literature review are described as follows. First, determine the sources for literature review materials in accordance with the topic of the study of this paper. Second, evaluate the content contained in the designated literature study sources. This section contains matters relating to basic assumptions or facts that are considered true without verification and limitations, namely certain aspects that are used as a frame of mind. This analysis is needed to arrange the flow of thinking in solving problems. Third, make a summary of the contents of literature study sources. And fourth, exploring new thoughts and ideas on the topic of study to determine the position as the next research material.

\section{Results}

\subsection{Service Dominant Logic (SDL)}

Marketing as a model of economic exchange initially had a dominant logic which was based on the exchange of products, known as the Goods-Dominant Logic. Good-Dominant Logic focuses on the separation between producers and consumers and it is still used. This aims to maximize production control, efficiency and profit maximization. This is usually achieved by standardizing the product and producing it away from the market [10].

Vargo, S. L. and Lusch, R. F (2004), introduce a new dominant logic that is different from the goods-dominant logic [11]. The dominant-logic focuses on the interaction between producers, consumers, and colleagues in the supply network as well as value creation as parties who co-create value through a collaborative process. This logic is known as Service-Dominant logic [10].

\subsection{Value Co-Creation}

Traditionally, suppliers produce goods and services, and customers buy goods and services. However, nowadays, customers can engage in dialogue with suppliers during each stage of product design and product delivery [6].

Around 1980 thought began to undergo a transition which manifested itself in terms of service marketing, relationship marketing, views of exchange and competition based on resources and so on. Marketing shifts from a good dominant logic to a service dominant logic where intangible goods, exchange processes, and relationships with consumers are central issues. [10]

Central to the dominant logic of service (S-D) is the proposition that customers become cocreators of value. It emphasizes developing customer-supplier relationships through interaction and dialogue [6]. Together, producers and customers have the opportunity to create value through custom, 
co-production offerings. Value co-creation is a desirable goal because it can assist the company in highlighting the customer's point of view and in improving the start-to-end process in identifying the needs and desires of Lusch and Vargo's 2006 customers in [6].

Co-creation is the process of involving stakeholders from outside the company, such as customers, business partners, etc., in the process of developing new products and services by using their experiences by way of discussion and exchange of ideas. Co-creation is about running a business with the thrill of being a consumer in real time. This is a continuous dialogue about the possibility of cocreation, something new, innovative, personalized co-creation experience and its environment [12].

The literature on value co-creation has been widely carried out in the manufacturing industry, but there is still little literature on co-creation in the service industry, especially in education. This paper will explore the literature related to the role of customer resources, especially customer education and customer expertise on value co-creation activities.

Alves et al., (2016), in their paper mentions several customer operant resources variables that affect value co-creation activities [5]. Among them are customer education, self-efficacy, customer expertise, and social bridges. Alves found that all of these variables have a positive effect on cocreation activities. Alves also examines how customer education through customer expertise has a positive effect on co-creation activities.

Traditionally, the role of the customer is considered passive, limited to consumer goods and services and subject to the marketing activities of the producer [13]. Customers now increasingly need to be satisfied, customers now play an important role in business systems, customers play an important role for the company. Their position as those who will consume their products makes the position of consumers so important for a company.

The recent evolution of marketing leads to a new dominant logic, which focuses more on intangible, dynamic, operan resources that are central to competitive advantage and performance [1]

The main activity of educational institutions is to provide educational services. In several ways, HE service activities can be compared to business activities in general, particularly service business activities. HE in some ways can be equated with a business enterprise. For HE to survive, it must carry out organizational management that adheres to the principles of good governance. Higher education also has its customers. The service industry must be customer-oriented. HE should takes a high response to the desires of various students who become consumers [7]. Theoretically, the success of a company is determined by the company's ability to define who its customers are, and the ability to satisfy their needs [8].

As a continuation of the RBV theory, put forward the Resource Advantage Theory (R-A Theory). Like the RBV theory, basically the R-A theory argues that in competition, performance emerges from the market position, while market position arises from the advantages of the resources owned by the company [8].

\subsection{Resource Advantage Theory (R-A Theory)}

As a continuation of the RBV theory, put forward the Resource Advantage Theory (R-A Theory). Like the RBV theory, basically the R-A theory argues that in competition, performance emerges from the market position, while market position arises from the advantages of the resources owned by the company.

In the resource advantage theory, resources are corporate entities, both tangible and intangible, that can produce market offerings effectively and efficiently and have value for several market segments [14]. So in this case the resource type can be either an operand resource or an operant resource. Operand resources are physical resources that are static, such as machines and raw materials. Meanwhile, operant resources are dynamic resources such as humans, related to skills and knowledge; 
organization, related to supervision, routine and organizational culture; information, related to knowledge of market segments, technology and competitors; and relationships, relating to relationships with competitors, suppliers and consumers. It is said that the service-centered view is based on and consistent with the resource advantage theory because in this view the main competencies, basic knowledge, and expertise of economic entities that represent potential competitive advantages are introduced and developed.

\subsection{Customer Operant Resources}

Customer Operant Resources are resources owned by customers which are intangible / invisible (non-physical) resources that can take the form of consumer knowledge and capacity. Alves, H.Ferreira (2016) owned by the customer, among them skills, experiences, self confidence, knowledge, etc [5].

Universities can complement customer capacities and skills through training and education thereby increasing their scope of co-creation. The higher level of understanding of the opportunities available, the better value of co-creation [6]. Allowing customers to add their skills and knowledge will help improve practice creation [5].

By educating customers, HE equip customers with the capacities and abilities needed to coproduce services [5].

Customer education has long been seen as an effort to create value for customers. Education is an effort made by companies to help customers realize the full potential of the products they buy, solving various problems that may arise. Customer education can be a source of differentiating advantage as well as a source of vulnerability [15].

This paper aims to demonstrate the ability of the variable customer expertise to mediate the relationship between customer education and value co-creation activities in HE.

\subsection{The Role of The Customer In Value Co-Creation Activities}

This paper uses the Service Dominant Logic theory to explain the relationship between customer operant resources on value co-creation activities and competitive advantage. SDL theory explains that there is an interaction between producers, consumers, and colleagues in the supply network as well as value creation as parties who co-create value through a collaborative process.

Customers are identified as important stakeholders, they have a very important role in the value co-creation process. Among these roles is customer as co-producer, co-innovator, co-ideator, codesigner, co-developer, dan co-promoter [16].

Vargo, S. L. and Lusch, R. F (2004), says Operant resources that produce more effect [11]. The role of relative operand resources began to shift in the late twentieth century as humans began to realize that skills and knowledge were the most important types of resources.

According to Vargo, S. L. and Lusch, R. F (2004), Prior to 1960, marketing was seen as a process of transferring ownership of goods and their physical distribution as an application of movement of goods [11]. In the traditional view, marketing focuses on operand resources or goods as units of exchange. Marketing literature seldom deals with intangible products or services, and when it comes to services, services are defined as an addition to the production and marketing of goods.

In an imperfect shape, expresses a goods-centered view (the goods-centered view) is as follows [11]:

1. The goal of economic activity is to make and distribute goods that can be sold.

2. To be sold, goods must have benefits and value during the production and distribution process and must be able to offer superior value compared to what is offered by competitors. 
3. The company must set the decision variables at a certain level that can maximize the profit from the sales output.

4. To maximize efficiency and control production, goods must be standardized and produced away from the market.

5. Goods can be stored until they are needed and then given to consumers.

Vargo, S. L. and Lusch, R. F (2004) proposes a change in perspective in marketing [4]. This change shows how the concept of dominant logic in marketing has transitioned from goods-dominant logics to service-dominant logic. The first column is goods-dominant logics, an output-based term which was widely used around the 1800s and dominated until 1980. In the goods-dominant logic, tangible output and discrete transactions are central issues. The goods-dominant logic focuses on the efficient production of tangible goods that have value through the exchange of shapes during the manufacturing process. This suggests standardization, keeping production away from the market and consumer interference, and storing output until it is sold. In this logic, distribution and marketing have a role to add value by generating the benefits of place, time, and ownership.

Service-dominant logic sees consumers as operant resources, resources that can act together with other resources, consumers are partners with whom the company can collaborate to create value and promote the 'marketing with' philosophy. In the service-dominant logic, knowledge and ability to collaborate are the key drivers for companies to be more successful in competition.

\subsection{The Role of Customer Education In Value Co-Creation Activities}

When companies create interactions with customers when they consume goods and services, the company is developing opportunities to create value co-creation with and for customers and also to influence their value fulfillment [17].

\subsection{The Role of Customer Expertise In Value Co-Creation Activities}

Customer expertise is a customer who has the ability to process information and act better due to the education and knowledge they have.

Bell and Eisengerich in his writing put forward the proposition that customers who have higher expertise can process more complex information. Meanwhile, it shows how customer expertise does not only show participation in the service production process but also can contribute to the production of more valueable services [5]. Conceptual framework for mediating customer expertise role can be seen in Fig. 1. 


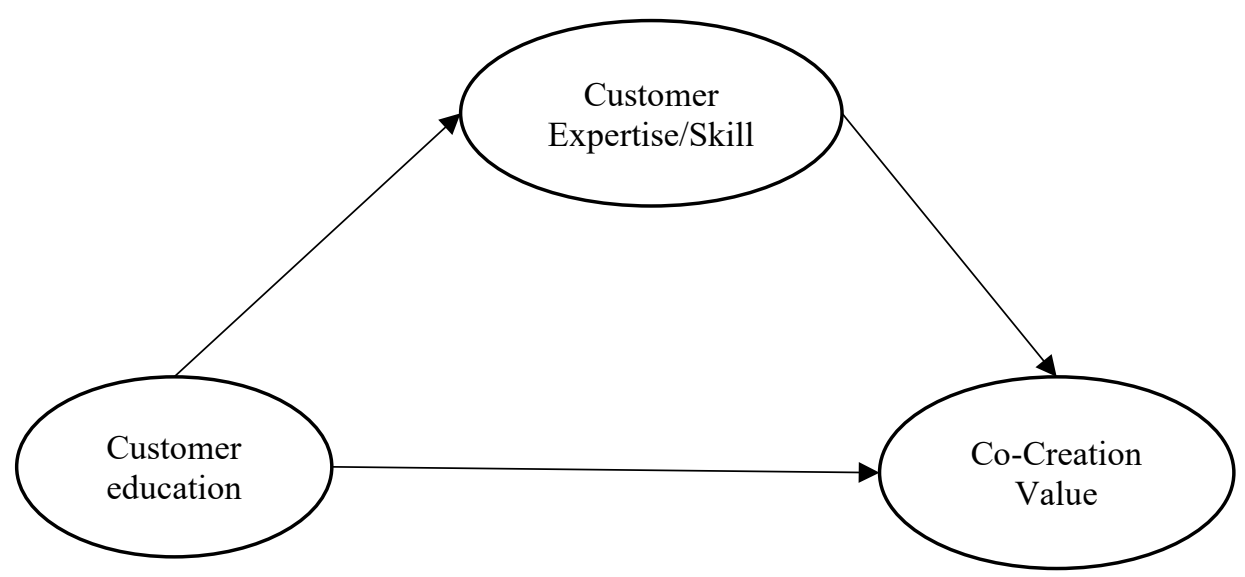

Fig. 1. Conceptual framework for Mediating Customer Expertise Role in the relationship between Customer Education and Value Co-creation.

\section{Discussion}

The framework has conceptualized the mediating role of customer expertise in relationship between customer education and value co-creation activities.

From theoretical view, this conceptual framework links and builds a logical framework for the relationship between customer education and value co-creation activities through customer expertise. This framework emphasizes the need for HE to continuously improve education for students and other stakeholders such as graduate users, employees and others so that they have more expertise in utilizing higher education services such as utilizing university websites, utilizing university programs such as community service (thematic KKN), thematic research so that in the end it has an impact on value cocreation activities in universities.

From applied view, this paper is expected to provide input and policy foundation for decision makers in higher education in order to formulate strategies and policies that prioritize and maximize the role of stakeholders (students, parents of students, graduate users, employees) in increasing co-creation value activities. This can improve and provide benefits to higher education in the form of stakeholder satisfaction, loyalty and competitive advantages of universities.

\section{Conclusion}

This paper produces a conceptual framework about relationship between customer education and value co-creation activities mediated by the variable customer expertise. Customer education is thought to have an effect on value co-creation and customer expertise is thought to be able to mediate the relationship between them. This paper needs to be followed up by conducting empirical research and testing the proposed model in order to find the expected results. 


\section{References}

[1] Madhavaram, S. and Hunt, S. D.: The Service-Dominant Logic And A Hierarchy Of Operant Resources: Developing Masterful Operant Resources And Implications For Marketing Strategy, J. Acad. Mark. Sci., vol. 36, no. 1, pp. 67-82, (2008), doi: 10.1007/s11747-007-0063-z.

[2] Prahalad, C. K. and Ramaswamy, V.: Co-Creation Experiences: The Next Practice In Value Creation, J. Interact. Mark., vol. 18, no. 3, pp. 5-14, (2004), doi: 10.1002/dir.20015.

[3] Krishna, A.: Co-Creation As A Competitive Advantage : New Dimensions And Paradigms, no. 4, pp. 79-83, (2013).

[4] Vargo, S. L.Maglio, P. P.and Akaka, M. A.: On Value And Value Co-Creation: A Service Systems And Service Logic Perspective, Eur. Manag. J., vol. 26, no. 3, pp. 145-152, (2008), doi: 10.1016/j.emj.2008.04.003.

[5] Alves, H.Ferreira, J. J.and Fernandes, C. I.: Customer's Operant Resources Effects On CoCreation Activities, J. Innov. Knowl., vol. 1, no. 2, pp. 69-80, (2016), doi: 10.1016/j.jik.2016.03.001.

[6] Payne, A. F.Storbacka, K.and Frow, P.: Managing The Co-Creation Of Value, J. Acad. Mark. Sci., vol. 36, no. 1, pp. 83-96, (2008), doi: 10.1007/s11747-007-0070-0.

[7] Uncles, M. D.: Directions In Higher Education: A Marketing Perspective, Australas. Mark. J., vol. 26, no. 2, pp. 187-193, (2018), doi: 10.1016/j.ausmj.2018.05.009.

[8] Purnama, H. N.: Menyoal Siapa Konsumen Perguruan Tinggi, pp. 7-8, (2006).

[9] Prahalad, C. K. and Ramaswamy, V.: Co-Creating Unique Value With Customers, Strateg. Leadersh., vol. 32, no. 3, pp. 4-9, (2004), doi: 10.1108/10878570410699249.

[10] Mardhiyah, D.: Perubahan Perspektif Dominant Logic, Serv. Domin. Log., vol. 1, no. 1, pp. 112, (2013).

[11] Vargo, S. L. and Lusch, R. F.: Evolving To A New Dominant Logic For Marketing, Serv. Log. Mark. Dialog, Debate, Dir., vol. 68, no. January, pp. 3-28, (2004).

[12] Adamik, A. and Nowicki, M.: Pathologies And Paradoxes Of Co-Creation: A Contribution To The Discussion About Corporate Social Responsibility In Building A Competitive Advantage In The Age Of Industry 4.0, Sustain., vol. 11, no. 18, (2019), doi: 10.3390/su11184954.

[13] Maria, T.Dimitris, P.Garifallos, F.Athanasios, G.and Roumeliotis, M.: Collaboration Learning As A Tool Supporting Value Co-Creation. Evaluating Students Learning Through Concept Maps, Procedia - Soc. Behav. Sci., vol. 182, pp. 375-380, (2015), doi: 10.1016/j.sbspro.2015.04.796.

[14] Wooliscroft, B. and Hunt, S. D.: The Evolution Of Resource-Advantage Theory: Six Events, Six Realizations, Six Contributions, J. Hist. Res. Mark., vol. 4, no. 1, pp. 7-29, (2012), doi: 10.1108/17557501211195046.

[15] Simon, B. and Andres, E.: The Paradox Of Customer Education: Customer Expertise And Loyalty In The Financial Services Industry, Eur. J. Mark., vol. 41, no. 5/6, pp. 466-486, (2016), doi: http://dx.doi.org/10.1108/MRR-09-2015-0216.

[16] Agrawal, A. K. and Rahman, Z.:Roles and Resource Contributions of Customers in Value Cocreation, vol. 3, no. 1-2. Holy Spirit University of Kaslik, (2015).

[17] Grönroos, C. and Ravald, A.: Service As Business Logic: Implications For Value Creation And Marketing, J. Serv. Manag., vol. 22, no. 1, pp. 5-22, (2011), doi: 10.1108/09564231111106893. 